\title{
Macrophage inflammatorv response mediated by intimin and bundle-forming pilus from enteropathogenic Escherichia coli
}

\author{
Bruna A. Caetano§, Daniela B. Mourão§ ${ }^{\sharp}$, Patrícia A. E. Abreu, Denize Monaris, Cynthia Soares \\ Galhardo $^{\sharp}$, Marcio A. Menezes ${ }^{\sharp}$, Halyka L. Vasconcellos $\#$, Daniela Luz ${ }^{\sharp}$, Flávia A. Lima, Waldir P. \\ Elias, Monamaris Marques Borges* and Roxane Maria Fontes Piazza*
}

Laboratório de Bacteriologia, Instituto Butantan, São Paulo, SP, Brasil.

$\S$ These authors contributed equally to this work.

\#Present address:

DBM - Laboratório de Química Forense, Superintendência de Polícia Técnico Científica, Avenida Nossa Sra. Da Penha, 2290 - 29045-402, Vitória, Espírito Santo, Brasil.

CSG - Setor de Triagem Sorológica - Fundação Pró-Sangue Hemocentro de São Paulo, Avenida Dr. Enéas Carvalho de Aguiar, 155 - 05403-000, São Paulo - SP, Brasil.

MAM - Laboratório de Técnicas Especiais - Biologia Molecular, Hospital Israelita Albert Einstein, Avenida Albert Einstein, 627 - 05652- 900 - São Paulo, SP, Brasil.

${ }^{*}$ Corresponding authors. Mailing address: RMFP and MMB - Laboratório de Bacteriologia, Instituto Butantan, Avenida Vital Brazil, 1500 - 05503-900, São Paulo, SP, Brazil. Phone +55 11 26279724. Email: roxane.piazza@butantan.gov.br; monamaris.borges@butantan.gov.br

+ Presented at the 1st International Electronic Conference on Microbiology, 2-30 November 2020; Available online: https://ecm2020.sciforum.net/

Published: 2 November 2020

\begin{abstract}
Enteropathogenic Escherichia coli (EPEC) are important agents of acute diarrhea in children living in developing countries. A severe dysfunction of the intestinal epithelial barrier occurs during EPEC infection, leading to diarrhea and inflammation as consequences. EPEC main virulence factors include the adhesins intimin and bundle-forming pilus (BFP), as well as several effector proteins translocated to the enterocyte by the type three-secretion system. The initial interaction of EPEC with the host cell and the role of effector proteins in this process are well known. However, the role of the EPEC virulence factors in macrophage activation is not fully understood. Hence, we analyzed the ability of intimin and $\mathrm{BfpA}$, to activate the innate response mediated by macrophages, where the production of the proinflammatory cytokines TNF- $\alpha$, IL-1, IL- 6 and IL-12, and the anti-inflammatory cytokine IL-10 and chemokine MCP-1 were evaluated. Our results showed that recombinant intimin and BfpA activate macrophages in dose-dependent manner, and the stimulated cells produced TNF- $\alpha$, IL-12 and IL-6, IL-10 and MCP-1, but not IL-1 $\beta$. No synergistic effect was observed in the production of proinflammatory cytokines by combining BfpA and intimin, although production of IL-10, an anti-inflammatory mediator, was potentiated at a higher dose. The effect observed was largely attributed to these proteins, as the treatment of proteins with polymyxin B did not alter the production of TNF- $\alpha$. Thus, herein we showed that intimin and BfpA can activate the innate immune response, inducing the production of pro and anti-inflammatory cytokines, as well as chemokines, playing additional role as inflammatory molecules in the early steps of EPEC infection.
\end{abstract}

Keywords: enteropathogenic E. coli; intimin; bundle-forming pilus (BfpA), macrophage; innate immune response; cytokines

\section{Introduction}


Enteropathogenic Escherichia coli (EPEC) is one of the six pathotypes comprising the diarrheagenic E. coli pathogroup, and still one of the major causes of acute diarrhea of children living in developing countries [1-5]. EPEC induce a distinctive histopathological lesion on the intestinal mucosa known as the attaching and effacing $(\mathrm{A} / \mathrm{E})$ lesion, which is characterized by the intimate adherence of EPEC to the epithelium, effacement of the intestinal microvilli and formation of pedestal-like structures under the site of attachment, in consequence of the reorganization of actin filaments [6].

After entering the gastrointestinal tract, EPEC adhere to the mucosa of the small and large intestines and at least three steps for pathogenesis have been described [7]. The initial step includes adherence to the host cell. After a multifactorial attachment via adhesive structures, in which the bundle-forming pilus (BFP) [8] is an important structure, a type III secretion system (T3SS) injects virulence factors in the enterocyte. Finally, an intimate bacterial attachment via intimin, an outer membrane adhesin of $94-\mathrm{kDa}$, and its translocated intimin receptor (Tir) leads to the pedestal formation [9-12].

In EPEC infections, inflammation is characteristic, due to increased cellular permeability. There is intense infiltration of neutrophils and lymphocytes in the lamina propria to the infection site [13] and other inflammatory cells, such as tissue macrophages, participate in the inflammatory response [14]. One of the consequences of EPEC infection is the regulation of signal transduction, culminating in the activation of NF- $\mathrm{KB}[15,16]$, which promotes the expression of cytokines. After the interaction of phagocytic cells with microorganisms or their products, secretion of several pro or antiinflammatory mediators occurs, including oxygen and nitrogen derivatives, cytokines such as IL-1, IL-6, IL-8, IL-10, IL-12, IL-18, TNF- $\alpha$ and chemokine's such as MCP-1, in addition to mediators derived from arachidonic acid [17-19]. This variety of components regulates adaptive immunity to be developed later.

Similarly, Dann et al. [20] demonstrated that in infections by Citrobacter rodentium, a murine intestinal pathogen widely used as an animal model of A/E lesion [20]. Macrophages and epithelial cells present in the colon expressing IL-6, a cytokine related to the recruitment and activation of neutrophils, in addition to induce the production of acute phase important for the efficient bacteria control. Also, Ramirez et al. [21], exploring the mucosal immune response in rabbits infected with rabbit-specific EPEC (REPEC), detected an increase in mRNA expression for IL-1 $\beta$, IL-6, IL-8, TNF- $\alpha$ and IL-10 produced by enterocytes during the developed diarrheal disorder.

The interaction of EPEC with the host intestinal epithelium induces an innate immune response that generates a local inflammatory response [22]. The degree of macrophage activation is one of the factors determining the severity of the inflammatory process, since these cells coordinate the resolution of inflammation [23]; consequently they are fundamental for phagocytosis and define the development of acquired immunity with reciprocal interaction between macrophages and activated $\mathrm{T}$ and $\mathrm{B}$ lymphocytes, providing novel levels of regulation and acquisition of antimicrobial resistance.

These cells, when activated, promote the resolution of the inflammatory process through the production of various cytokines, chemokines and growth factors [24]. The initial recognition of EPEC effector proteins by phagocytic cells has not been elucidated; thus, such information is crucial for understanding the inflammatory process generated during this infection. Since macrophages are highly heterogeneous in their functions and their activation depend on the nature of the stimulus and the environment to which they adapt [25], we investigated the pattern of cytokines after the initial contact of intimin and BfpA with primary bone marrow-derived macrophages. Our results suggest that intimin and $\mathrm{BfpA}$ are potent activators of the innate immune response that can contribute to the control of inflammation during EPEC infection.

\section{Materials and Methods}

\subsection{Ethics statement}


The experiments were conducted in agreement with the Ethical Principles in Animal Research, adopted by the Brazilian College of Animal Experimentation, and they were approved by the Ethical Committee for Animal Research of Butantan Institute (Protocol 537/08).

\subsection{Cloning, expression, and purification of recombinant intimin and BfpA proteins}

The intimin-encoding gene (eae) was amplified by PCR using as template the genomic DNA from EPEC serotype O111ab:H2 [26], expressing intimin classified as subtype beta-3 ( $\beta 3$ ). The following primers were used for amplification: F: GGATCCGCTAGCGCTTCGTCACAGTTGCAGGC and R: AAGCTTCGATCGCATATGTACTTGATACGCC. The underlined nucleotides indicate BamHI and HindIII restriction sites, respectively. The amplified fragment of 2,176 bp, corresponding to the intimin beta-3 gene without the signal peptide-encoding sequence, was purified, digested with Bam HI and HindIII and cloned into the same restriction sites of pQE30 expression vector (Qiagen, Venlo, NL). The obtained construct was verified by DNA sequencing with appropriate vector-specific primers and named as pFL 33 . Competent cells of the E. coli strain M15 (pREP4) (Qiagen, Venlo, NL) were transformed with pFL $\beta 3$ plasmid and grown in Luria-Bertani (LB) broth at $37^{\circ} \mathrm{C}$ under constant shaking $(250 \mathrm{rpm})$ until the optical density at $600 \mathrm{~nm}$ reached 0.6. The expression of recombinant intimin was induced with $1 \mathrm{mM}$ isopropyl-1-thio- $\beta$-D-galactopyranoside (IPTG) at $37{ }^{\circ} \mathrm{C}$ for $3 \mathrm{~h}$ under the same culture conditions. The $6 x$-His-tagged intimin $\beta 3$ was purified using metal affinity chromatography, as previously described [27].

E. coli DH5 $\alpha$ harboring the plasmid pEU84 [28] was used for BfpA production. This construction corresponds to the $b f p A$-encoding sequence from EPEC B171 cloned into the pQE-30 vector. The expression of recombinant BfpA in LB broth was induced with $0.4 \mathrm{mM}$ IPTG at $37^{\circ} \mathrm{C}$ for $3 \mathrm{~h}$ under constant shaking $(250 \mathrm{rpm})$. The $6 \mathrm{x}$-His-tag fusion BfpA was purified using metal affinity chromatography [29].

The production of these proteins was confirmed by immunoblotting employing the rabbit antiintimin IgG enriched fraction [30] or with rabbit anti-BfpA polyclonal serum (IgG) [31]. The level of endotoxin present in intimin and BfpA samples was tested by the Limulus Amebocyte Lysate (LAL) assay (Lonza, Basel, $\mathrm{CH}$ ), with a range from 0.125 to 1.25 Endotoxin Unit (EU)/ $\mu$ g proteins, considering that $1 \mathrm{EU}$ corresponds to $5 \mathrm{ng} / \mathrm{mL}$ of LPS.

\subsection{Macrophages}

Bone marrow derived macrophages (BMDM) were isolated from femur and tibia from female $\mathrm{C} 3 \mathrm{H} / \mathrm{HeJ}$ mice 6-8 weeks according to Weischenfeldt and Porse [32]. The cells were cultivated at 37 ${ }^{\circ} \mathrm{C}$ and $5 \% \mathrm{CO}_{2}$ for 7 days at $1 \times 10^{6} \mathrm{~mL}$ and $0.5 \mathrm{~mL}$ were plated in 48 well plates Costar (Corning, Corning, New York, USA) in RPMI 1640 medium (Gibco Invitrogen Corporation, Waltham, Massachusetts, USA) supplemented with 10\% fetal bovine serum (Gibco Invitrogen Corporation, Waltham, Massachusetts, USA), $0.2 \mathrm{mM} \mathrm{L-glutamine,} 50 \mathrm{UI} / \mathrm{mL}$ penicillin and $50 \mu \mathrm{g} / \mathrm{mL}$ streptomycin, $1 \mathrm{mM}$ sodium pyruvate, and $20 \%(\mathrm{v} / \mathrm{v})$ of the $\mathrm{L} 929$ cell culture supernatant. At day seven, the cells were washed with PBS pH 7.2, to remove the non-adherent cells, the adherent ones were maintained in the same medium. These cells were exclusively F4/80 (yield of 95\%), since this phenotype was confirmed by Flow Cytometry using monoclonal antibodies specific for $\mathrm{T}$ lymphocytes (anti-CD3), B-lymphocytes (anti-B220) and macrophages (anti-F4/80).

\subsection{Activation of $B M D M$ with intimin or $B f p A$}

Adherent BMDM ( $5 \times 10^{5}$ cells/well) were activated with $0.5 ; 1.0 ; 5.0$ and $10.0 \mu \mathrm{g} / \mathrm{mL}$ of intimin or BfpA associated or not and cultured at $37^{\circ} \mathrm{C}$ and $5 \% \mathrm{CO}_{2}$. The culture supernatant was harvested after $20 \mathrm{~h}$ of stimulation for TNF- $\alpha$, IL-1, IL-6, IL-10, IL-12 and MCP-1 assay. As a control another group of cells was stimulated with LPS $(2.5 ; 5 ; 10,50$ and $100 \mathrm{ng} / \mathrm{mL})$ 


\subsection{Effect of intimin and Bfp on BMDM viability}

The viability of BMDM treated with intimin and BfpA $(5-10 \mu \mathrm{g} / \mathrm{mL})$ for $20 \mathrm{~h}$ was determined by the activity of succinyl dehydrogenase, using 3-(4,5)-dimethyltialzolyl-2,5-diphenyltetrazolium bromide (MTT, $5 \mathrm{mg} / \mathrm{mL}$, Sigma-Aldrich, San Luis, Missouri, USA) as substrate [33]. After $4 \mathrm{~h}$ of incubation at $37{ }^{\circ} \mathrm{C}$ and $5 \% \mathrm{CO}_{2}$ the crystals were solubilized using v/v of $0.1 \mathrm{~N} \mathrm{HCl}$ solution in isopropyl alcohol and the optical density (DO) was determined using an ELISA reader (Multiskan EX, Primary EIA, Thermo Fisher Scientific, Waltham, Massachusetts, USA) at $550 \mathrm{~nm}$. Cells treated with $0.1 \%$ Triton X-100 representing 100\% death and macrophages without treatment were used as a $100 \%$ viability control.

\subsection{Effect of intimin and $B f p A$ treatment with polymyxin $B$ and proteinase $K$.}

To confirm the specificity of recombinant proteins intimin or BfpA $(1.5$ and $10 \mu \mathrm{g} / \mathrm{mL})$ were preincubated for $1 \mathrm{~h}$ at $37^{\circ} \mathrm{C}$ with polymyxin B $(30 \mu \mathrm{g} / \mathrm{mL})$ or proteinase $\mathrm{K}(50 \mu \mathrm{g} / \mathrm{mL})$. Subsequently samples were added to cultures of the J774 A.1 Mouse BALB/c macrophage-like cell line maintained in RPMI 1640 medium (Gibco Invitrogen Corporation, Waltham, Massachusetts, USA) containing 10\% FBS (Gibco Invitrogen Corporation, Waltham, Massachusetts, USA) and $50 \mu \mathrm{g} / \mathrm{mL}$ gentamicin and incubated at $37^{\circ} \mathrm{C}$ and $5 \%$ CO2 for $24 \mathrm{~h}$. The LPS $(100 \mathrm{ng} / \mathrm{mL})$ and Bovine Serum albumin (BSA, $10 \mu \mathrm{g} / \mathrm{mL}$, Sigma-Aldrich, San Luis, Missouri, USA) were used as a control [34,35]. The level of TNF$\alpha$ was analyzed in the culture supernatant comparing groups treated or not with the respective drugs.

\subsection{Cytokines assays}

The presence of the following cytokines TNF- $\alpha$, IL-1, IL-6, IL-10 and IL-12 and the chemokine MCP-1 in the BMDM culture supernatant were analyzed using the immunoenzymatic assay (ELISA) from the eBioscience kit following manufacturer's recommendation (Thermo Fisher Scientific, Waltham, Massachusetts, USA).

\subsection{Statistical analysis}

The results represent the mean and standard error of the mean (SEM) of 3-4 independent experiments and were analyzed by the GraphPad Prism $5 \AA$ program. Differences were considered significant when $\mathrm{p}<0.05$ by the unpaired Student $\mathrm{t}$ test.

\section{Results}

\subsection{Intimin and BfpA had no effect on BMDM viability}

Recombinant Intimin and BfpA were purified and their identity were confirmed by immunoblotting using specific antibodies (Figure S1). These proteins were employed throughout the experiments. Initially the effect of both proteins on the viability of BMDM was investigated using the MTT assay. These proteins did not cause cytotoxic effect, regardless of the employed concentration (5 and $10 \mu \mathrm{g} / \mathrm{mL}$ ). The optical density values were close to the control groups (absence of recombinant proteins) (Figure S2). 
A

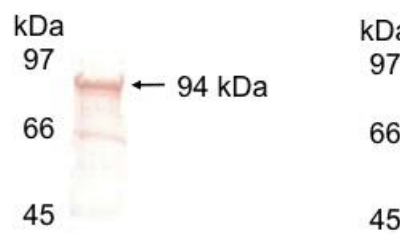

30

20

14

30

14
B

$20 \leftarrow 20 \mathrm{kDa}$

Figure S1. Expression of the proteins intimin $\beta 3$ and BfpA. Nitrocellulose membranes containing purified protein fractions of intimin $\beta 3(94 \mathrm{kDa})$ and $\mathrm{BfpA}(20 \mathrm{kDa})$ were incubated in the presence of rabbit specific IgG followed by goat anti-rabbit IgG peroxidase-conjugated. A: intimin $3 \beta$ protein; B: BfpA protein.

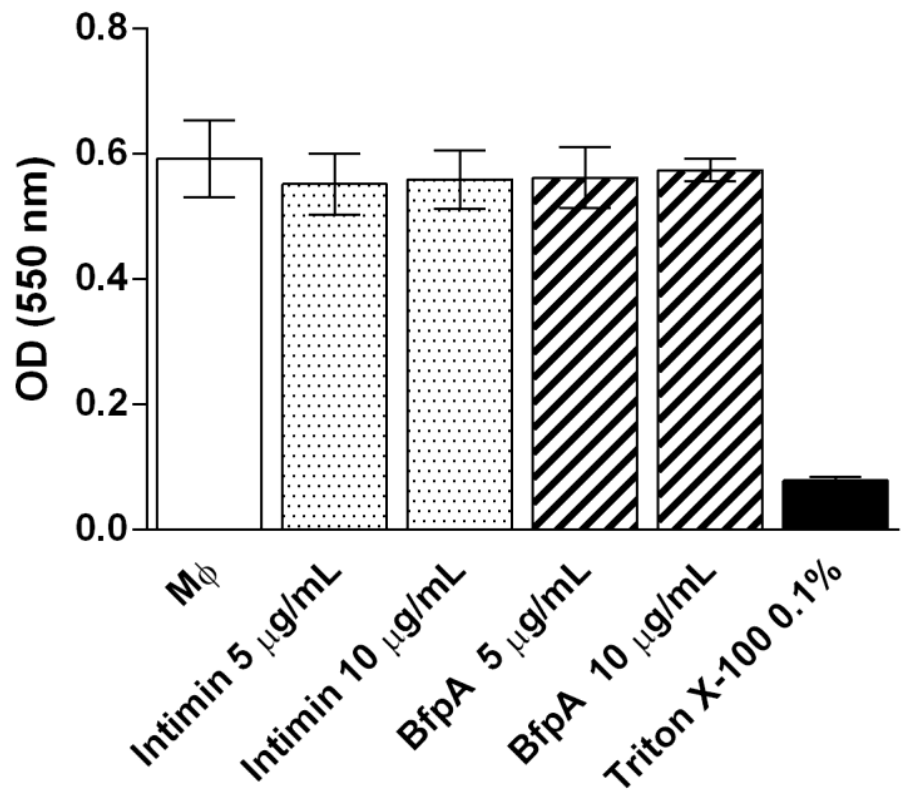

Figure S2. Cell viability of macrophages after treatment with intimin and BfpA. M $\varphi(6 \times 105$ cells) were stimulated with intimin and BfpA $(5 \mu \mathrm{g} / \mathrm{mL}$ and $10 \mu \mathrm{g} / \mathrm{mL})$ for 20 hours. Cell viability was determined by the MTT assay. Triton X-100 (0.1\%) was used as a cytotoxicity control. The results are representative of the

\subsection{Role of intimin and BfpA in BMDM activation}

The interaction of EPEC with the host's intestinal epithelial cells has been widely studied and proven to generate a local inflammatory response [14]. Macrophages coordinate the severity and resolution of inflammation in this inflammatory site. Since the role of intimin and BfpA in the activation of these cells during EPEC intestinal colonization is not well understood, we investigated their effect on the activation of medullary macrophages.

Intimin and BfpA proteins induced dose-dependent cytokine synthesis. We found that $1 \mu \mathrm{g} / \mathrm{mL}$ of both proteins was sufficient to activate the macrophages, however $5-10 \mu \mathrm{g} / \mathrm{mL}$ had more 
pronounced and significant effects ( $\mathrm{p}<0.0001)$. This profile was repeated for the pro-inflammatory mediators IL-6 and IL-12p40. However, we emphasize that the level of these mediators was much higher than that described for TNF- $\alpha$. The synthesis of IL-12p40 was more prominent in comparison to other cytokines production (Figure 1). No difference was observed between intimin and BfpA in terms of the ability to stimulate macrophages, with the levels of cytokines being analyzed close to each other regardless of the nature of the stimulus.

The effect of intimin and BfpA on the synthesis of the anti-inflammatory cytokine IL-10 and chemokine MCP-1 was investigated. Only cells treated with 5 and $10 \mu \mathrm{g} / \mathrm{mL}$ of intimin and BfpA produced significant level of IL-10 ( $p<0.0001)$ (Figure 1). However, these cells synthesized high levels of chemokines, especially MCP-1 and IL-12 that were dose dependent. IL-1 $\beta$ was not detected in the culture supernatants. These data confirm the ability of intimin and BfpA to activate macrophages during EPEC infection. 

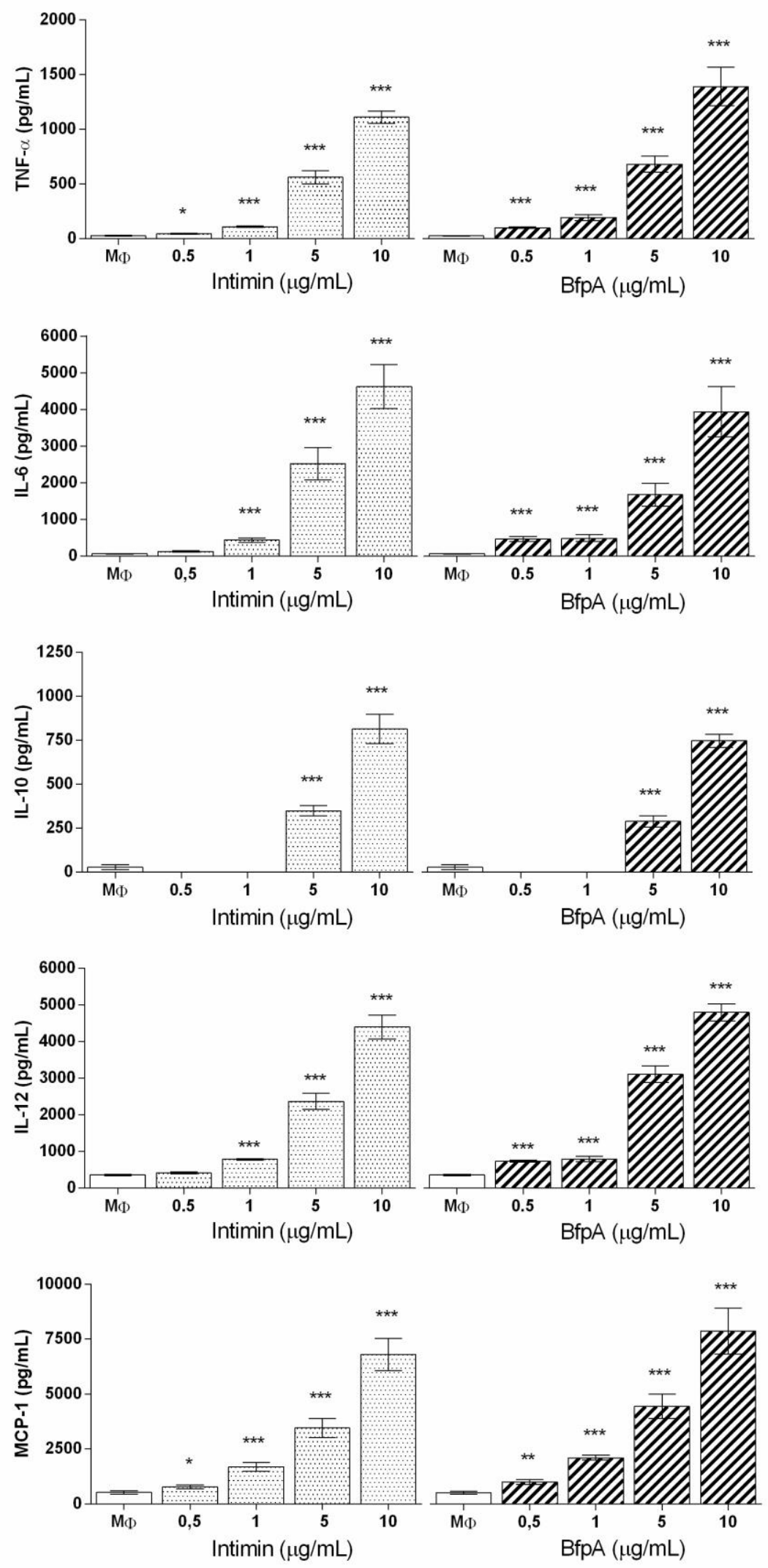

Figure 1. $\mathrm{M} \varphi\left(6 \times 10^{5}\right.$ cells $)$ were stimulated with 0.5 to $10 \mu \mathrm{g} / \mathrm{mL}$ of intimin or BfpA for $20 \mathrm{~h}$. The synthesis of cytokines and chemokine was analysed in the culture supernatant by the ELISA assay. Data represent the mean \pm SEM of three independent experiments, performed in duplicate. The values ${ }^{*} \mathrm{p}<0.05,{ }^{* *} \mathrm{p}<0.001$ or ${ }^{* * *} \mathrm{p}<0.0001$ were considered significant. 


\subsection{Intimin and BfpA do not work synergistically to activate BMDM}

Microorganism proteins may improve the effect on the inflammatory processes [17-19]. Herein, this effect was investigated by combining intimin plus BfpA during BMDM activation. We demonstrated that $10 \mu \mathrm{g} / \mathrm{mL}$ of intimin or BfpA increased the production of chemokines TNF- $\alpha$ and MCP-1 in BMDM culture. However, the treatment of macrophages with both proteins did not change the level of these cytokines (Figure 2). Analysis of IL-6 and IL-10 production showed a slight increase in the level of these cytokines, and for IL- 6 the observed difference was only in response to BfpA $(p>0.05)$. The role of intimin in combination with BfpA was significantly observed in the synthesis of IL-10 ( $p>0.001$ ) when compared to these proteins separately (Figure 2). This suggests that, during an EPEC infection, IL-10 production depends on the concentration of these EPEC virulence factors present at the site of infection.
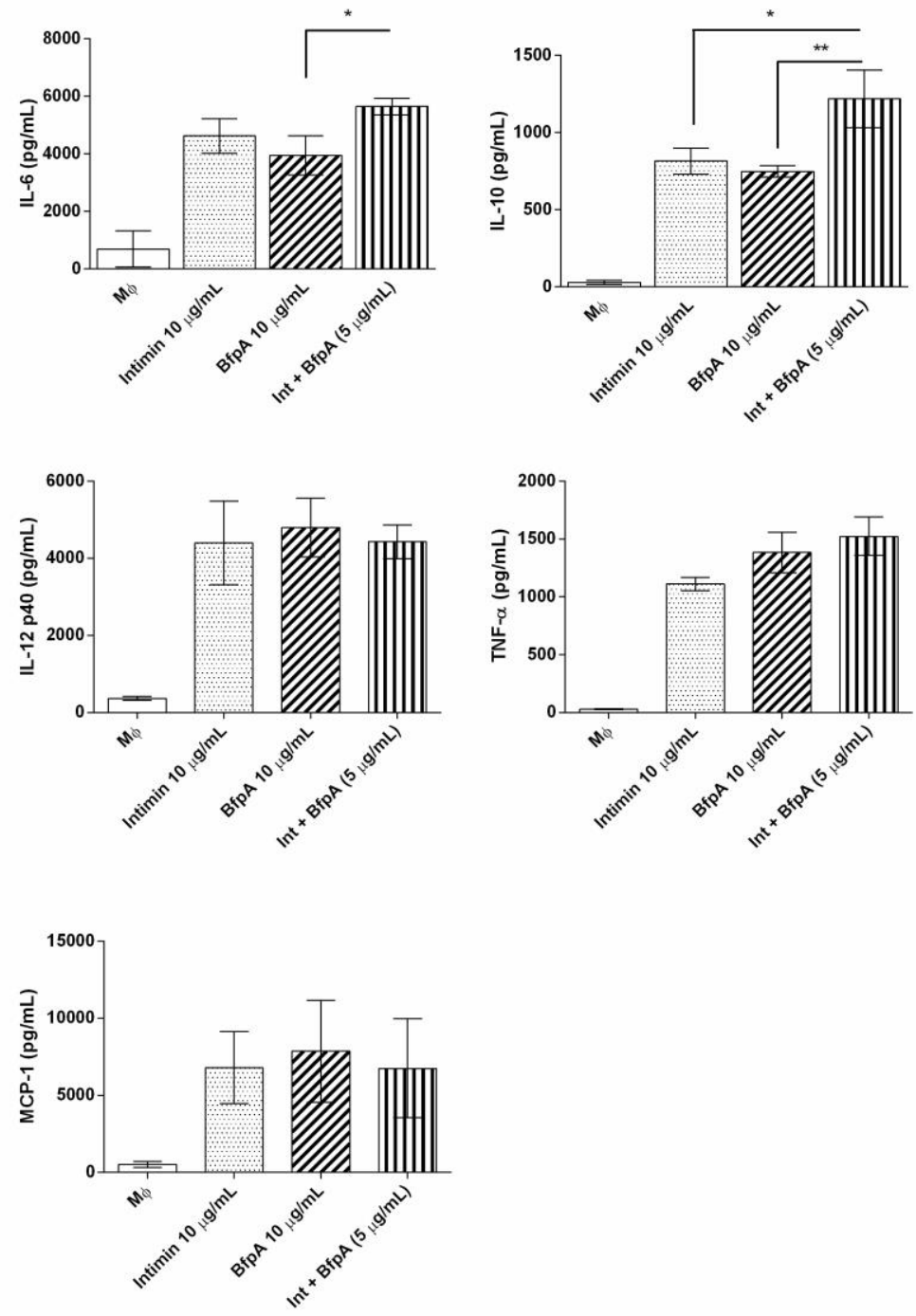

Figure 2. $\mathrm{M} \varphi\left(6 \times 10^{5}\right.$ cells $)$ were stimulated with the combination of intimin and BfpA $(5 \mu \mathrm{g} / \mathrm{mL}$ and $5 \mu \mathrm{g} / \mathrm{mL}$ ). After $20 \mathrm{~h}$ the supernatant was obtained for cytokines and chemokine measurement. The results are representative of the mean \pm SEM of three independent experiments, performed in duplicate. The values ${ }^{*} \mathrm{p}<0.05$ and ${ }^{* *} \mathrm{p}<0.001$ were considered significant.

\subsection{The immune response mediated by intimin and BfpA was specific}

To confirm the specificity of intimin and BfpA in macrophages activation, both proteins were pre-treated before phagocytic cells stimulation with polymyxin B, which interacts with LPS, or proteinase $\mathrm{K}(\mathrm{PK})$, which is capable of breaking peptide bonds between protein amino acids. The J774 
A.1 cell line was used for this assay due to its high sensitivity to endotoxins. The activation of these cells with intimin or BfpA pretreated with polymyxin B induced the production of large amounts of TNF- $\alpha$, in a dose dependent manner; however, the treatment of LPS $(100 \mathrm{ng} / \mathrm{mL})$ with polymyxin B reduced drastically the level of TNF- $\alpha$ to similar level of untreated controls (Figure 3A). These results indicate that the immune response detected was due to the proteins intimin and BfpA and not endotoxins.

Subsequently, we evaluated the influence of the treatment of the two recombinant proteins with PK on the activation of the J774 phagocytic cells. As shown in Figure 3B intimin and BfpA individually stimulated the synthesis of high levels of TNF- $\alpha$. The pretreatment of these proteins with PK inhibited the TNF- $\alpha$ response by $100 \%$, obtaining values close to those found in untreated cultures $(\mathrm{p}<0.0001)$ (Figure 3B). These data differ in cells stimulated with LPS $(100 \mathrm{ng} / \mathrm{mL})$, since the treatment with proteinase $\mathrm{K}$ did not significantly inhibit the production of this cytokine. Thus, these data confirmed that the activation of macrophages by intimin and BfpA was not due to the action of endotoxins, but rather due to the protein activity of these molecules.

A

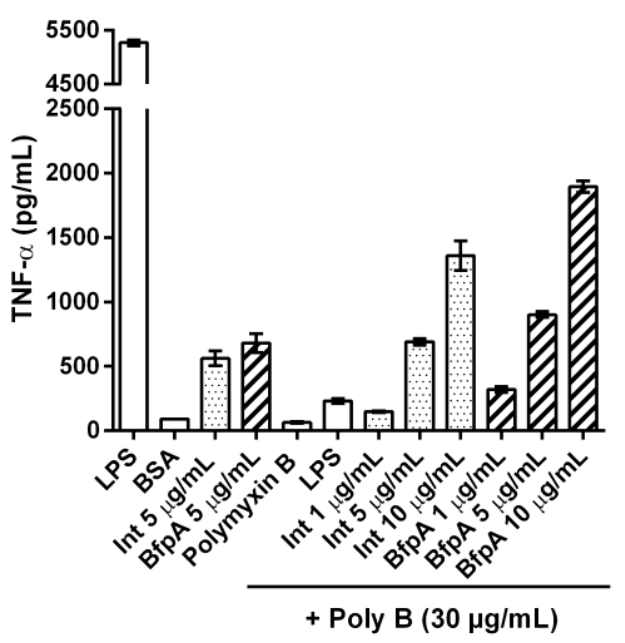

B

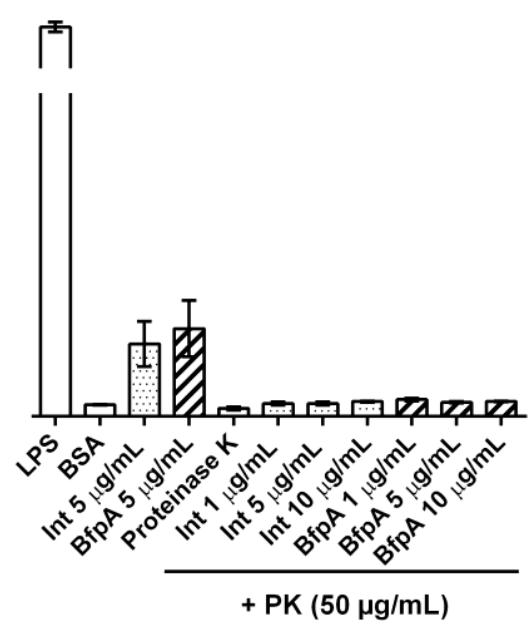

Figure 3. J774 cells $\left(6 \times 10^{5}\right.$ cells) were stimulated with either intimin or BfpA pretreated with $30 \mu \mathrm{g} / \mathrm{mL}$ of polymyxin B (A) and $50 \mu \mathrm{g} / \mathrm{mL}$ of proteinase $\mathrm{K}$ (B) for $20 \mathrm{~h}$. The supernatant was obtained to measure TNF- $\alpha$. The results are representative of the mean \pm SEM of two independent experiments, performed in triplicate.

\section{Discussion}

EPEC infection starts with intestinal epithelium colonization leading to an intimate adherence that triggers the $\mathrm{A} / \mathrm{E}$ lesion and inflammation $[6,13,14]$. Several virulence factors contribute to these steps, including BFP and intimin as adhesins as well as several effector proteins injected into the host cell via the T3SS [36]. Nevertheless, the mechanisms behind the inflammation process in the early stages of the infection are not completely known.

We employed intimin and BfpA recombinant proteins to test their role during the first contact with bone marrow derived macrophages (BMDM), which is the origin of the various macrophage populations distributed in the organism, and the consequences for the inflammatory response. It was shown that the treatment of BMDM with recombinant intimin and BfpA did not change the viability of these cells. The fact that these cells respond to the stimulus with these proteins synthesizing inflammatory mediators and chemokines strongly suggests their viability.

During the EPEC intimate binding to the host cell, proteins associated with the T3SS are translocated directly to the infected cell, modifying and subverting the host cells function, including those of the immune system, to cause diarrhea [37]. Most of the studies with EPEC virulence factors 
explore epithelial cells as a target; however the role of these effector proteins in macrophage activation and consequences for the immune system is not fully understood.

The different steps of EPEC pathogenesis are associated with specific virulence factors [38]. Among them, the fimbrial adhesin BFP is responsible for the initial adherence to the enterocytes and contributes to the inflammatory response $[3,39]$. Intimin is an outer membrane protein that binds to epithelial cells through its receptor Tir [37], which is essential for the establishment of the AE lesion and can determine tropism by different sites in the intestine [40]. Due to their importance in the early steps of the EPEC pathogenesis, they were chosen for our studies. Initially, the recombinants BfpA [29] and intimin $\beta 3$ were produced.

Macrophages represent one of the main cells of the innate immune system, with multiple functions, adapted to the tissues where they reside. They are fundamental for phagocytosis and define the development of acquired immunity with reciprocal interaction with activated $\mathrm{T}$ and $\mathrm{B}$ lymphocytes. When activated, they promote the resolution of the inflammatory process by releasing large amounts of immune mediators [41]. The impact of innate immunity on intestinal host defense against $\mathrm{A} / \mathrm{E}$ bacterial pathogens remains an unresolved.

$\mathrm{BfpA}$ and intimin stimulated in a dose dependent manner pro-inflammatory cytokines such as TNF- $\alpha$, IL- 6 and IL-12p40, as well as the anti-inflammatory IL-10, in addition to the chemokine MCP1 . However, the presence of IL-1 $\beta$ was not detected. The IL-10 synthesis was dependent of intimin high concentrations or BfpA, while low doses of these proteins were sufficient for production of proinflammatory cytokines.

The specific response of the proteins intimin and BfpA was demonstrated in the assays where these recombinants were pretreated with polymyxin $\mathrm{B}$ or proteinase $\mathrm{K}$. The microenvironment created during inflammation is important to contain the infection. Excessive production of proinflammatory mediators in addition to being toxic to microorganisms can be toxic to the host cell [23]. To balance the inflammatory response, the presence of anti-inflammatory cytokines is essential [14].

When used in combination, intimin and BfpA did not modify the production profile of proinflammatory mediators; only anti-inflammatory IL-10 was enhanced. The IL-10 inhibits the production of pro-inflammatory cytokines through negative feedback [42,43]. Sharma and collaborators [44] suggests that during epithelial cell inflammation induced by T3SS proteins, different proteins act by balancing the induction of pro or anti-inflammatory response. The same can occur with BMDM activated with a high concentration of intimin and BfpA, to balance the inflammatory response of macrophages and to define the immune response to be generated later.

Intimin and BfpA are involved with the local inflammatory response, and the presence of MCP1 (monocyte chemoattractant protein-1), which confirms this hypothesis, as it recruits leukocytes for the endothelium, in addition to controlling the activation of tissue macrophages [45]. The migration of neutrophils, monocytes and the presence of tissue macrophages located just below the intestinal mucosa, are essential in the resolution of the inflammatory process, due to the release of immune mediators that favor the migration of cells to the inflammatory focus and present antigens for the local lymphocytes. To compensate, intestinal macrophages perform their anti-inflammatory function to neutralize tissue damage and restore homeostasis [46].

Toll-like (TLRs) and NOD-like receptors (NLR) are important for the initiation of the innate immune response [47]. The NOD-like receptor (NLR) regulates the processing and secretion of IL-1 $\beta$ via caspase- 1 activation [48]. The absence of apoptosis and IL-1 $\beta$ in the macrophage culture supernatant suggests that intimin and BfpA do not use this signaling pathway. Toll-like receptors (TLRs) that are located on the surface and on the endosomal membrane recognize patterns of molecules conserved in bacteria (PAMPs) [49]. Although we have not studied the direct action of these receptors, the binding of PAMPs to these receptors activates inflammatory signaling pathways and leads to the production of inflammatory cytokines to further propagate and amplify the immune response [49]. The inflammatory activity of BfpA and intimin is not associated with TLR4, since macrophages from $\mathrm{C} 3 \mathrm{H} / \mathrm{HeJ}$ mice (tlr4 -/-) were considered hypo-responder to endotoxins [50]. The treatment of cells with the maximum dose of intimin plus BfpA $(10 \mu \mathrm{g} / \mathrm{mL})$ did not potentiate the synthesis of TNF- $\alpha$ or MCP-1. 
In conclusion, our findings show that intimin and BfpA activate the innate immune response, inducing the production of cytokines (pro and anti-inflammatory) and chemokine's independent of TLR-4, playing an additional role as an inflammatory molecule at the beginning of the infection. Understanding the complexity of the interaction between virulence factors and macrophages will help to clarify the pathogenesis and immune response of EPEC infection and may assist in future treatment strategies.

Fundings: This work was supported by grants from the São Paulo Research Foundation (FAPESP) to WPE (2004/12136-7), RMFP (2009/14845-7) and MMB (2013/11212-9). RMFP and WPE are fellows from the Conselho Nacional de Desenvolvimento Científico e Tecnológico (CNPq). BAC is recipient of a scholarship from FAPESP (grant 2016/16188-7). DBM was recipient of a scholarship from CNPq.

Conflicts of Interest statement: The authors declare that the research was conducted in the absence of any commercial or financial relationships that could be construed as a potential conflict of interest.

Author Contributions statement: DBM, PAEA, MMB and RMFP participated in the design of the study. DBM, DM, HLV, CSG, MAM and DL carried out the experiments. BAC, DBM, PAEA, MMB and RMFP participated in data analysis. PAEA, WPE, MMB and RMFP contributed reagents/materials/analysis tools; BAC, MMB, WPE and RMFP participated in writing the manuscript. All authors read and approved the final version of the manuscript.

\section{References}

1. Ochoa, T.J.; Contreras, C.A. Enteropathogenic Escherichia coli infection in children. Curr Opin Infect Dis 2011, 24, 478-483, doi:10.1097/QCO.0b013e32834a8b8b.

2. Panchalingam, S.; Antonio, M.; Hossain, A.; Mandomando, I.; Ochieng, B.; Oundo, J.; Ramamurthy, T.; Tamboura, B.; Zaidi, A.K.M.; Petri, W., et al. Diagnostic Microbiologic Methods in the GEMS-1 Case/Control Study. Clinical Infectious Diseases 2012, 55, S294-S302, doi:10.1093/cid/cis754.

3. Gomes, T.A.; Elias, W.P.; Scaletsky, I.C.; Guth, B.E.; Rodrigues, J.F.; Piazza, R.M.; Ferreira, L.C.; Martinez, M.B. Diarrheagenic Escherichia coli. Braz J Microbiol 2016, 47 Suppl 1, 3-30, doi:10.1016/j.bjm.2016.10.015.

4. Platts-Mills, J.A.; Liu, J.; Rogawski, E.T.; Kabir, F.; Lertsethtakarn, P.; Siguas, M.; Khan, S.S.; Praharaj, I.; Murei, A.; Nshama, R., et al. Use of quantitative molecular diagnostic methods to assess the aetiology, burden, and clinical characteristics of diarrhoea in children in low-resource settings: a reanalysis of the MAL-ED cohort study. Lancet Glob Health 2018, 6, e1309-e1318, doi:10.1016/S2214-109X(18)30349-8.

5. Merino, V.R.; Nakano, V.; Delannoy, S.; Fach, P.; Alberca, G.G.F.; Farfan, M.J.; Piazza, R.M.F.; AvilaCampos, M.J. Prevalence of Enteropathogens and Virulence Traits in Brazilian Children With and Without Diarrhea. Frontiers in Cellular and Infection Microbiology 2020, doi:10.3389/fcimb.2020.549919.

6. Moon, H.W.; Whipp, S.C.; Argenzio, R.A.; Levine, M.M.; Giannella, R.A. Attaching and effacing activities of rabbit and human enteropathogenic Escherichia coli in pig and rabbit intestines. Infect Immun 1983, 41, 1340-1351, doi:10.1128/IAI.41.3.1340-1351.1983.

7. Donnenberg, M.S.; Kaper, J.B. Enteropathogenic Escherichia coli. Infect Immun 1992, 60, 3953-3961, doi:10.1128/IAI.60.10.3953-3961.1992.

8. Girón, J.A.; Ho, A.S.; Schoolnik, G.K. An inducible bundle-forming pilus of enteropathogenic Escherichia coli. Science 1991, 254, 710-713, doi:10.1126/science.1683004.

9. Jerse, A.E.; Yu, J.; Tall, B.D.; Kaper, J.B. A genetic locus of enteropathogenic Escherichia coli necessary for the production of attaching and effacing lesions on tissue culture cells. Proc Natl Acad Sci U S A 1990, 87, 7839-7843, doi:10.1073/pnas.87.20.7839.

10. Frankel, G.; Phillips, A.D.; Novakova, M.; Field, H.; Candy, D.C.; Schauer, D.B.; Douce, G.; Dougan, G. Intimin from enteropathogenic Escherichia coli restores murine virulence to a Citrobacter rodentium eaeA mutant: induction of an immunoglobulin A response to intimin and EspB. Infect Immun 1996, 64, 5315-5325.

11. Kenny, B.; DeVinney, R.; Stein, M.; Reinscheid, D.J.; Frey, E.A.; Finlay, B.B. Enteropathogenic E. coli (EPEC) transfers its receptor for intimate adherence into mammalian cells. Cell 1997, 91, 511-520, doi:10.1016/s00928674(00)80437-7.

12. Dean, P.; Kenny, B. The effector repertoire of enteropathogenic E. coli: ganging up on the host cell. Curr Opin Microbiol 2009, 12, 101-109, doi:10.1016/j.mib.2008.11.006.

13. Ulshen, M.H.; Rollo, J.L. Pathogenesis of Escherichia coli gastroenteritis in man-another mechanism. N Engl J Med 1980, 302, 99-101, doi:10.1056/NEJM198001103020207. 
14. Sanchez-Villamil, J.; Navarro-Garcia, F. Role of virulence factors on host inflammatory response induced by diarrheagenic Escherichia coli pathotypes. Future Microbiol 2015, 10, 1009-1033, doi:10.2217/fmb.15.17.

15. Zhou, X.; Girón, J.A.; Torres, A.G.; Crawford, J.A.; Negrete, E.; Vogel, S.N.; Kaper, J.B. Flagellin of enteropathogenic Escherichia coli stimulates interleukin-8 production in T84 cells. Infect Immun 2003, 71, 2120-2129, doi:10.1128/iai.71.4.2120-2129.2003.

16. Santos, A.S.; Finlay, B.B. Bringing down the host: enteropathogenic and enterohaemorrhagic Escherichia coli effector-mediated subversion of host innate immune pathways. Cell Microbiol 2015, 17, 318-332, doi:10.1111/cmi.12412.

17. Mahida, Y.R. The key role of macrophages in the immunopathogenesis of inflammatory bowel disease. Inflamm Bowel Dis 2000, 6, 21-33, doi:10.1097/00054725-200002000-00004.

18. Gordon, S. Alternative activation of macrophages. Nat Rev Immunol 2003, 3, 23-35, doi:10.1038/nri978.

19. Mantovani, A.; Sica, A.; Locati, M. New vistas on macrophage differentiation and activation. Eur J Immunol 2007, 37, 14-16, doi:10.1002/eji.200636910.

20. Dann, S.M.; Spehlmann, M.E.; Hammond, D.C.; Iimura, M.; Hase, K.; Choi, L.J.; Hanson, E.; Eckmann, L. IL-6-dependent mucosal protection prevents establishment of a microbial niche for attaching/effacing lesion-forming enteric bacterial pathogens. J Immunol 2008, 180, 6816-6826, doi:10.4049/jimmunol.180.10.6816.

21. Ramirez, K.; Huerta, R.; Oswald, E.; Garcia-Tovar, C.; Hernandez, J.M.; Navarro-Garcia, F. Role of EspA and intimin in expression of proinflammatory cytokines from enterocytes and lymphocytes by rabbit enteropathogenic Escherichia coli-infected rabbits. Infect Immun 2005, 73, 103-113, doi:10.1128/IAI.73.1.103113.2005.

22. Lebeis, S.L.; Sherman, M.A.; Kalman, D. Protective and destructive innate immune responses to enteropathogenic Escherichia coli and related A/E pathogens. Future Microbiol 2008, 3, 315-328, doi:10.2217/17460913.3.3.315.

23. Gea-Sorlí, S.; Closa, D. Role of macrophages in the progression of acute pancreatitis. World J Gastrointest Pharmacol Ther 2010, 1, 107-111, doi:10.4292/wjgpt.v1.i5.107.

24. Fujiwara, N.; Kobayashi, K. Macrophages in inflammation. Curr Drug Targets Inflamm Allergy 2005, 4, 281286.

25. Murray, P.J.; Wynn, T.A. Protective and pathogenic functions of macrophage subsets. Nat Rev Immunol 2011, 11, 723-737, doi:10.1038/nri3073.

26. Campos, L.C.; Whittam, T.S.; Gomes, T.A.; Andrade, J.R.; Trabulsi, L.R. Escherichia coli serogroup O111 includes several clones of diarrheagenic strains with different virulence properties. Infect Immun 1994, 62, 3282-3288, doi:10.1128/IAI.62.8.3282-3288.1994.

27. Monaris, D.; Sbrogio-Almeida, M.E.; Dib, C.C.; Canhamero, T.A.; Souza, G.O.; Vasconcellos, S.A.; Ferreira, L.C.; Abreu, P.A. Protective Immunity and Reduced Renal Colonization Induced by Vaccines Containing Recombinant Leptospira interrogans Outer Membrane Proteins and Flagellin Adjuvant. Clin Vaccine Immunol 2015, 22, 965-973, doi:10.1128/CVI.00285-15.

28. de Almeida CM, Quintana-Flores VM, Medina-Acosta E, Schriefer A, Barral-Netto M, Dias da Silva W. Egg yolk anti-BfpA antibodies as a tool for recognizing and identifying enteropathogenic Escherichia coli. Scand J Immunol. 2003, 57, 573-582. doi: 10.1046/j.1365-3083.2003.01243.x.

29. Vasconcellos, H.L.; Scaramuzzi, K.; Nascimento, I.P.; Da Costa Ferreira, J.M.; Abe, C.M.; Piazza, R.M.; Kipnis, A.; Dias da Silva, W. Generation of recombinant bacillus Calmette-Guérin and Mycobacterium smegmatis expressing BfpA and intimin as vaccine vectors against enteropathogenic Escherichia coli. Vaccine 2012, 30, 5999-6005, doi:10.1016/j.vaccine.2012.05.083.

30. Menezes, M.A.; Rocha, L.B.; Koga, P.C.; Fernandes, I.; Nara, J.M.; Magalhães, C.A.; Abe, C.M.; Ayala, C.O.; Burgos, Y.K.; Elias, W.P., et al. Identification of enteropathogenic and enterohaemorrhagic Escherichia coli strains by immunoserological detection of intimin. J Appl Microbiol 2010, 108, 878-887, doi:10.1111/j.13652672.2009.04484.x.

31. Nara, J.M.; Cianciarullo, A.M.; Culler, H.F.; Bueris, V.; Horton, D.S.; Menezes, M.A.; Franzolin, M.R.; Elias, W.P.; Piazza, R.M. Differentiation of typical and atypical enteropathogenic Escherichia coli using colony immunoblot for detection of bundle-forming pilus expression. I Appl Microbiol 2010, 109, 35-43, doi:10.1111/j.1365-2672.2009.04625.x.

32. Weischenfeldt, J.; Porse, B. Bone Marrow-Derived Macrophages (BMM): Isolation and Applications. CSH Protoc 2008, 2008, pdb.prot5080, doi:10.1101/pdb.prot5080. 
33. Mosmann, T. Rapid colorimetric assay for cellular growth and survival: application to proliferation and cytotoxicity assays. J Immunol Methods 1983, 65, 55-63.

34. Cooperstock, M.S. Inactivation of endotoxin by polymyxin B. Antimicrob Agents Chemother 1974, 6, 422-425, doi:10.1128/aac.6.4.422.

35. Sandri, S.; Rodriguez, D.; Gomes, E.; Monteiro, H.P.; Russo, M.; Campa, A. Is serum amyloid A an endogenous TLR4 agonist? J Leukoc Biol 2008, 83, 1174-1180, doi:10.1189/jlb.0407203.

36. Cleary, J.; Lai, L.C.; Shaw, R.K.; Straatman-Iwanowska, A.; Donnenberg, M.S.; Frankel, G.; Knutton, S. Enteropathogenic Escherichia coli (EPEC) adhesion to intestinal epithelial cells: role of bundle-forming pili (BFP), EspA filaments and intimin. Microbiology-Sgm 2004, 150, 527-538, doi:10.1099/mic.0.26740-0.

37. Vallance, B.A.; Finlay, B.B. Exploitation of host cells by enteropathogenic Escherichia coli. Proc Natl Acad Sci U S A 2000, 97, 8799-8806, doi:10.1073/pnas.97.16.8799.

38. Humphries, R.M.; Armstrong, G.D. Sticky situation: localized adherence of enteropathogenic Escherichia coli to the small intestine epithelium. Future Microbiol 2010, 5, 1645-1661, doi:10.2217/fmb.10.124.

39. Edwards, L.A.; Bajaj-Elliott, M.; Klein, N.J.; Murch, S.H.; Phillips, A.D. Bacterial-epithelial contact is a key determinant of host innate immune responses to enteropathogenic and enteroaggregative Escherichia coli. PLoS One 2011, 6, e27030, doi:10.1371/journal.pone.0027030.

40. Phillips, A.D.; Frankel, G. Intimin-mediated tissue specificity in enteropathogenic Escherichia coli interaction with human intestinal organ cultures. J Infect Dis 2000, 181, 1496-1500, doi:10.1086/315404.

41. Mantovani, A.; Biswas, S.K.; Galdiero, M.R.; Sica, A.; Locati, M. Macrophage plasticity and polarization in tissue repair and remodelling. J Pathol 2013, 229, 176-185, doi:10.1002/path.4133.

42. Gordon, S.; Plüddemann, A.; Martinez Estrada, F. Macrophage heterogeneity in tissues: phenotypic diversity and functions. Immunol Rev 2014, 262, 36-55, doi:10.1111/imr.12223.

43. Krause, P.; Morris, V.; Greenbaum, J.A.; Park, Y.; Bjoerheden, U.; Mikulski, Z.; Muffley, T.; Shui, J.W.; Kim, G.; Cheroutre, H., et al. IL-10-producing intestinal macrophages prevent excessive antibacterial innate immunity by limiting IL-23 synthesis. Nat Commun 2015, 6, 7055, doi:10.1038/ncomms8055.

44. Sharma, R.; Tesfay, S.; Tomson, F.L.; Kanteti, R.P.; Viswanathan, V.K.; Hecht, G. Balance of bacterial proand anti-inflammatory mediators dictates net effect of enteropathogenic Escherichia coli on intestinal epithelial cells. Am J Physiol Gastrointest Liver Physiol 2006, 290, G685-694, doi:10.1152/ajpgi.00404.2005.

45. Hine, A.M.; Loke, P. Intestinal Macrophages in Resolving Inflammation. J Immunol 2019, 203, 593-599, doi:10.4049/jimmunol.1900345.

46. Bosurgi, L.; Cao, Y.G.; Cabeza-Cabrerizo, M.; Tucci, A.; Hughes, L.D.; Kong, Y.; Weinstein, J.S.; LiconaLimon, P.; Schmid, E.T.; Pelorosso, F., et al. Macrophage function in tissue repair and remodeling requires IL-4 or IL-13 with apoptotic cells. Science 2017, 356, 1072-1076, doi:10.1126/science.aai8132.

47. Dolasia, K.; Bisht, M.K.; Pradhan, G.; Udgata, A.; Mukhopadhyay, S. TLRs/NLRs: Shaping the landscape of host immunity. Int Rev Immunol 2018, 37, 3-19, doi:10.1080/08830185.2017.1397656.

48. Wen, H.; Miao, E.A.; Ting, J.P. Mechanisms of NOD-like receptor-associated inflammasome activation. Immunity 2013, 39, 432-441, doi:10.1016/j.immuni.2013.08.037.

49. Kumar, H.; Kawai, T.; Akira, S. Toll-like receptors and innate immunity. Biochem Biophys Res Commun 2009, 388, 621-625, doi:10.1016/j.bbrc.2009.08.062.

50. Poltorak, A.; He, X.; Smirnova, I.; Liu, M.Y.; Van Huffel, C.; Du, X.; Birdwell, D.; Alejos, E.; Silva, M.; Galanos, C., et al. Defective LPS signaling in $\mathrm{C} 3 \mathrm{H} / \mathrm{HeJ}$ and C57BL/10ScCr mice: mutations in Tlr4 gene. Science 1998, 282, 2085-2088, doi:10.1126/science.282.5396.2085.

Publisher's Note: MDPI stays neutral with regard to jurisdictional claims in published maps and institutional affiliations.

(C) 2020 by the authors; licensee MDPI, Basel, Switzerland. This article is an open access article distributed under the terms and conditions of the Creative Commons Attribution (CC-BY) license (http://creativecommons.org/licenses/by/4.0/). 